\title{
Corrigendum
}

Hilary Chappell* and Denis Creissels

\section{Corrigendum to: Topicality and the typology of predicative possession}

https://doi.org/10.1515/lingty-2019-5001

Corrigendum to: Chappell, Hilary and Denis Creissels. November 2019. Topicality and the typology of predicative possession. Linguistic Typology. Volume 23, Issue 3, pages 467-532. (DOI:10.1515/lingty-2019-0016):

The authors would like to make the following corrections to their article:

In Example (36b) on page 497, a character is incorrect. The sentence should be 王有梦，不隹害 instead of 王有梦，不佳害

Example (70) on page 513 contains an incorrect symbol and an omission. The correct version is this:

Cái-gì có cánh đều bay được.

CL-what EPP wing all fly be.possible

'Whatever has wings can fly.'

On page 514, line 8, it should be "Shuhi" instead of "Shihu".

\footnotetext{
*Corresponding author: Hilary Chappell, Ecole des Hautes Etudes en Sciences Sociales, Centre de Recherches Linguistiques sur l'Asie Orientale, CRLAO, INaLCO, 2 rue de Lille, 75007 Paris, France, E-mail: hmchappell@gmail.com

Denis Creissels, Laboratoire Dynamique du Langage (UMR 5596 du CNRS), Université Lyon 2, DDL-ISH, 14 avenue Berthelot, 69007 Lyon, France, E-mail: Denis.Creissels@univ-lyon2.fr
} 